\section{Electrochemical study of Propolis as anti-oxidative reagent against to lead ions in rabbit blood samples using cyclic voltammetry}

Muhammed Mizher RADHI - Radiology, Health and Medical Technology College-Baghdad, Middle Technology University, Iraq - mmradhi@yahoo.com

BAHAA FAKHRI HUSSEIN - College of Veterinary Medicine, University of Baghdad, Baghdad, Iraq Ahmed Adeeb MOHAMED - College of Veterinary Medicine, University of Baghdad, Baghdad, Iraq Érkezett: 2018. 11. 16. " Received: 16. 11. 2018. - https://doi.org/10.14382/epitoanyag-jsbcm.2019.6

\section{Abstract}

One of the causes of autism disease is known to be the contamination of lead compounds for pregnant women or the children. The purpose of the research is to be proven the effect of lead ions by in vivo method on the samples of rabbit blood using cyclic voltammetric technique and to identify the effect of the antioxidant reagent namely propolis compound. The electrochemical analysis method was used in this study by cyclic voltammetric technique to determine the effect of propolis on the oxidation current peak of lead ions in blood medium (samples of rabbit blood). It was found that propolis compound acts as antioxidative reagent to reduce the oxidation current peak of lead ions to minimize value of current, it means that propolis compound is doing to eliminating the effect of lead ions in the blood and preventing it from precipitating the lead ions on the brain through the stream of blood in the animal body.

Keywords: lead ions, blood medium, cyclic voltammetry, GCE, propolis, autism, rabbit Kulcsszavak: ólom ionok, vér közeg, ciklikus voltammetria, GCE, propolisz, autizmus, nyúl

\section{Muhammed Mizher RADHI \\ Professor, Department of Radiological Techniques, Health and Medical Technology College-Baghdad, Middle Technical University, Baghdad, Iraq. He received his PhD from University Putra of Malaysia (UPM) at 2010 in Electrochemistry, Nanotechnology. Research topics: conductivity of grafted polymer with nano-deposit and fabrication of sensors by nanomaterials to study drugs in blood medium by electrochemical analysis.}

Bahaa Fakhri HUSSEIN Assistant Professor: anatomy and histology department, College of Veterinary Medicine, University of Baghdad, Baghdad, Iraq. He received his PhD from University Putra of Malaysia (UPM) at 2010 in bone tissue engineering. Research topics: tissue engineering and stem cells.

Ahmed Adeeb MOHAMED PhD student in anatomy and histology, College of Veterinary Medicine, University of Baghdad, Iraq

\section{Introduction}

Many scientists have studied the effect of lead ions in different electrolytes such as blood medium to determine the oxidative effect of lead ion [1-5].

Propolis or bee glue is a resinous mixture that honey bees produce by mixing saliva and beeswax with exudate gathered from tree buds, sap flows, or other botanical sources [6,7]. Blood samples of rabbits were studied before and after given propolis during which clinical signs, body weight, mortality rate and histopathological changes associated with challenge of rabbits with $P$. multocida strain were recorded [8]. It is possible to prove protective roles of propolis against $\mathrm{Pb}$-induced neurotoxicity. The results showed that co-administration of propolis with $\mathrm{Pb}$ inhibited $\mathrm{Pb}$-induced neurological toxicity, as indicated by normalization of inhibition of brain MDA and PCC formation. Also, propolis protects the mitochondrial NADH-cytochrome $\mathrm{C}$ reductase, $\mathrm{SDH}$ and cytochrome $\mathrm{C}$ activities from $\mathrm{Pb}$-induced amelioration. Furthermore, propolis increased vitamin C, vitamin E and P-SH levels in rat's brain. It can be concluded that propolis has beneficial effects and could be able to antagonize $\mathrm{Pb}$-induced neurotoxicity [9]. Propolis has been attracting scientific attention since it has many biological and pharmacological properties, which are related to its chemical composition. Several in vitro and in vivo studies have been performed to characterize and understand the diverse bioactivities of propolis and its isolated compounds, as well as to evaluate and validate its potential. Yet, there is a lack of information concerning clinical effectiveness. The aim of this review is to discuss the potential of propolis for the development of new drugs by presenting published data concerning the chemical composition and the biological properties of this natural compound from different geographic origins [10]. Oxidative stress seems to play a very important role in the carcinogenic process. Reactive oxygen species (ROS) can elicit multiple effects by mediating carcinogen activation, causing DNA damage, and interfering with the repair machinery of the damaged DNA. In addition, ROS levels increases in preneoplastic cells during their promotion stage. This seems to induce the growth of initiated cells, and to play a role during cell cycle progression either by further damage the unstable genetic material or by altering the growth of tumor cells. Thus, tumor cells continually undergo high and persistent oxidative stress by ROS although this stress does not appear to be enough to induce cell death. On the contrary, as a hormetic effect, pleneoplastic cells show increased cell resistance to ROS because the cell antioxidant mechanisms are induced. Thus, they showed high levels of internal antioxidants such as coenzyme Q $(\mathrm{CoQ})$ and are also able to accumulate high levels of ascorbate and reduced glutathione. These high levels of endogenous antioxidants may increase the chemotherapeutic resistance of the cells [11].

In this work, it was used a new method to prove that propolis compound can act as inhibition reagent for oxidation lead ions in the brain of rabbits.

\section{Experimental}

\subsection{Materials}

Groups of five 1.5-2 year old local breed rabbits (Oryctolagus cuniculus) weighting $\sim 1.5 \mathrm{~kg}$ were used. One group was injected intraperitoneally (IP) with $1 \mathrm{mg} / \mathrm{kg}$ lead acetate (Central Drug 
House, Leiden, Netherlands) dissolved in distilled water and another injected lead but also and fed orally $750 \mathrm{mg} / \mathrm{kg}$ propolis and deionized water for dilute the blood samples.

\subsection{Apparatus}

Instruments: EZstat series (potentiostat/glvanostat) NuVant Systems Inc. pioneering electrochemical technologies USA. Electrochemical workstations of Bioanalytical system with potetio-state driven by electroanalytical measuring software was connected to personal computer to perform cyclic voltammetry (CV), glassy carbon electrode (GCE), $\mathrm{Ag} / \mathrm{AgCl}$ $(3 \mathrm{M} \mathrm{NaCl})$ and Platinum wire $(1 \mathrm{~mm}$ diameter) was used as a working, reference and counter electrode respectively. The surface of GCE was cleaned by polishing with alumina solution and about ten minutes in sonic water path to remove any impurities before using in the cell of CV.

\subsection{Procedure}

Each sample of rabbit blood (volume of $1 \mathrm{ml}$ ) was diluted with $9 \mathrm{ml}$ of deionized water, the mixture placed in quartz cell of $10 \mathrm{ml}$, three electrodes (glassy carbon electrode as working electrode, $\mathrm{Ag} / \mathrm{AgCl}$ as reference electrode and platinum wire as counter electrode) were immersed in the mixture of blood sample. The three electrodes were connected with potentiostat to determine the results by the cyclic voltammogram using personal computer [12].

\section{Results and discussion}

\subsection{Effect lead ions on the blood components at different period weeks}

Results are shown in Table 1 and represented in Figs. 1 and 2. Electrochemical analysis of cyclic voltammetry of lead ion oxidation in blood produced a current peak of $400 \mathrm{mV}$ with $8.64 \mathrm{uA}$ in the $1^{\text {st }}$ week after injection of rabbit with lead $\mathrm{Pb}(\mathrm{II})$. In those fed with propolis, the current reduced to $3.8 \mathrm{uA}$, a difference of $(\triangle \mathrm{Ipa})$ about $4.84 \mathrm{uA}$. By the third to 8 period of testing the differences remained. By the $9^{\text {th }}$ week we obtained a peak of $16.8 \mathrm{uA}$ in that had been exposed to lead where in that propolis, voltage reduced to $3.53 \mathrm{uA}$ a difference of $13.27 \mathrm{uA}$. The findings suggest that propolis may have reduce oxidation by lead ions in blood $[13,14]$.

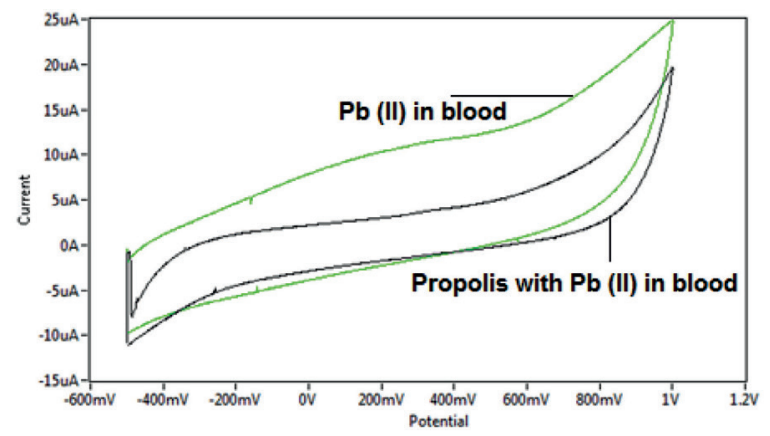

Fig. 1. Cyclic voltammograms measured in rabbit blood with lead ions or propolis (with lead ions as well) during the first week of tests; GCE as working electrode versus $\mathrm{Ag} / \mathrm{AgCl}(3 \mathrm{M} \mathrm{NaCl})$ as reference electrode.

1. ábra Ciklikus voltammogramok; nyúl vér minták ólom tartalommal, propolisszal etetve vagy anélkül, a vizsgálatok elsö hetében; mérő elektróda: GCE referencia elektróda: $\mathrm{Ag} / \mathrm{AgCl}(3 \mathrm{M} \mathrm{NaCl})$.

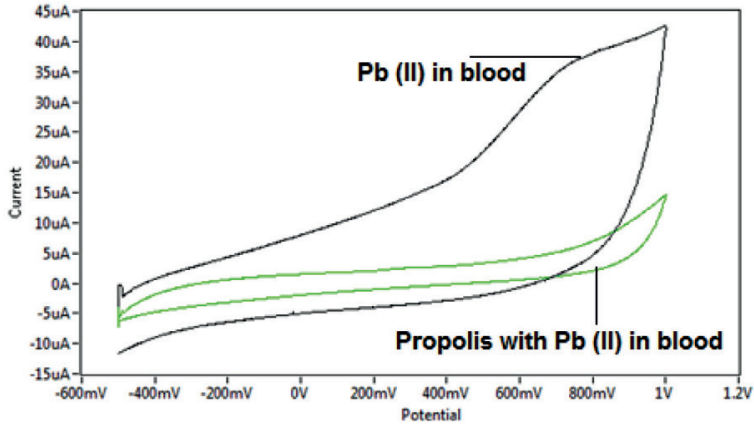

Fig. 2. Cyclic voltammograms measured in rabbit blood with lead ions or propolis (with lead ions as well) during the $9^{\text {th }}$ week of tests; GCE as working electrode versus $\mathrm{Ag} / \mathrm{AgCl}(3 \mathrm{M} \mathrm{NaCl})$ as reference electrode.

2. ábra Ciklikus voltammogramok; nyúl vér minták ólom tartalommal, propolisszal etetve vagy anélkül, a vizsgálatok kilencedik hetében; mérö elektróda: GCE, referencia elektróda: $\mathrm{Ag} / \mathrm{AgCl}(3 \mathrm{M} \mathrm{NaCl})$

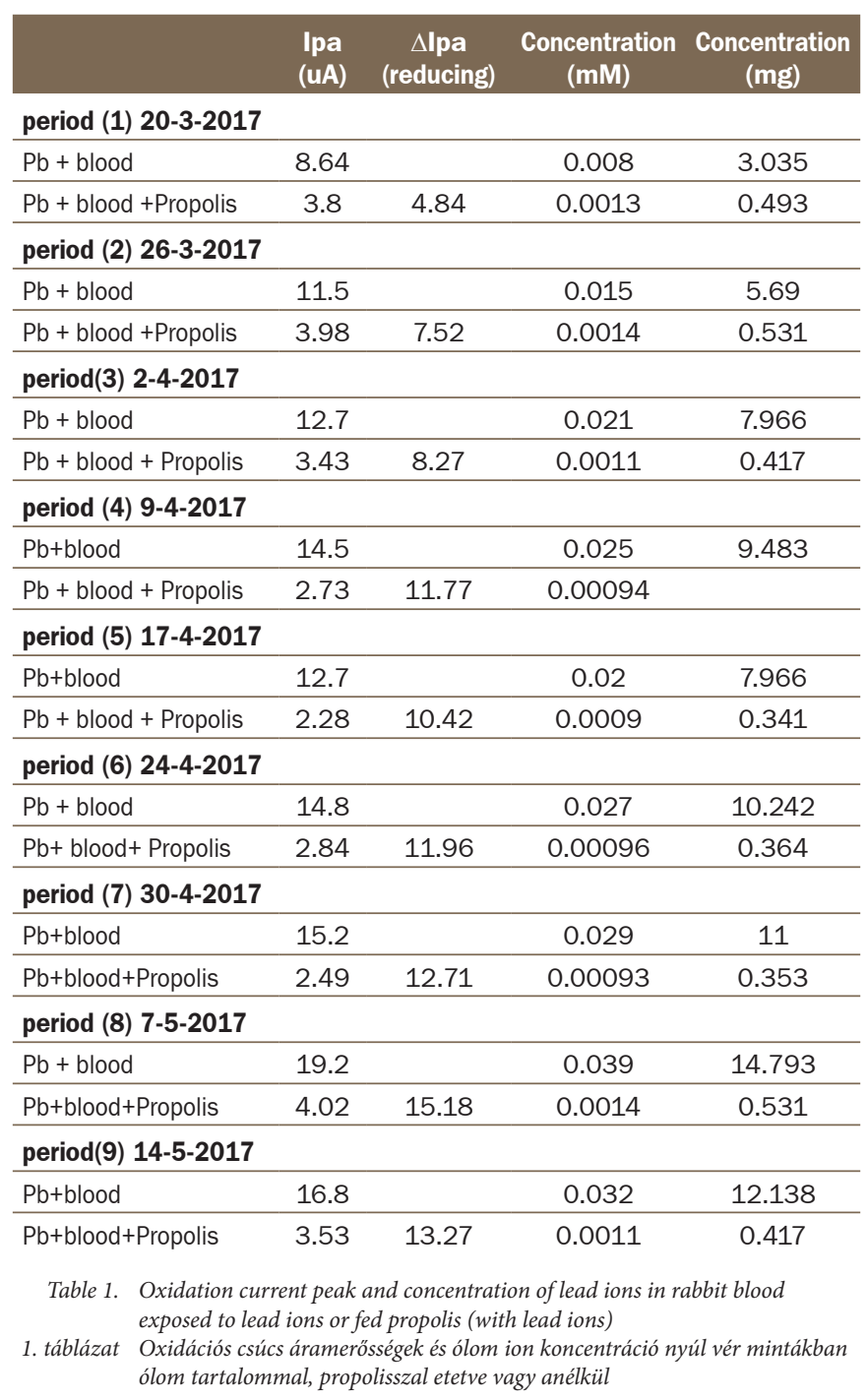

\subsection{Effect the concentration of $\mathrm{Pb}$ (II) in blood samples} before and after feeding omega 3 fatty acid on the rabbit

Lead ions in blood were measured by cyclic voltammetry. One group of 5 rabbits was injected $1 \mathrm{mg} / \mathrm{kg}$ lead acetate dissolved in distilled water. Another group of 5 rabbits were injected $1 \mathrm{mg} / \mathrm{kg}$ lead acetate IP but also fed $750 \mathrm{mg} / \mathrm{kg}$ propolis. A plot of lead concentration in blood versus time shows that 
lead concentrations increased over time with a correlation of $\mathrm{R}^{2}=0.85$ as shown in Fig 3. In those given propolis with lead the concentration of lead declined over time as shown in Fig. 4 as reported by others [15-17].

In vivo study of rabbit blood samples have been searched by electrochemical method using cyclic voltammetric technique to find the effect of presence of lead ions in the blood samples which received from injected rabbit with $\mathrm{Pb}(\mathrm{II})$, other blood samples were received from rabbit feeding with propolis after injected with $\mathrm{Pb}(\mathrm{II})$ dose. Both samples were studied to find the effect of oxidant reagent (lead ions) and antioxidant reagent (propolis) on blood component. It was found the concentration of lead ions in blood sample was increased against to period week as shown in Table 1 and Fig. 3. A good sensitivity was calculated from the relationship in the Fig. 3 is equal to 0.85 . On the other hand, the concentration of lead ions in blood sample of feeding rabbit with propolis was decreased as shown in Table 1 and Fig. 4. It means that omega compound was affected on the lead ions in blood medium which act inhibition of oxidative effect, so omega works to reduce lead action on the blood components [18-20].

It can be said that any blood contaminated with lead ions causes atrophy in the brain, this leads to symptoms of Alzheimer's disease in the adults or autism disease in children [21-23]. But, it was found that propolis was stopped the negative effective of lead ions especially in brain.

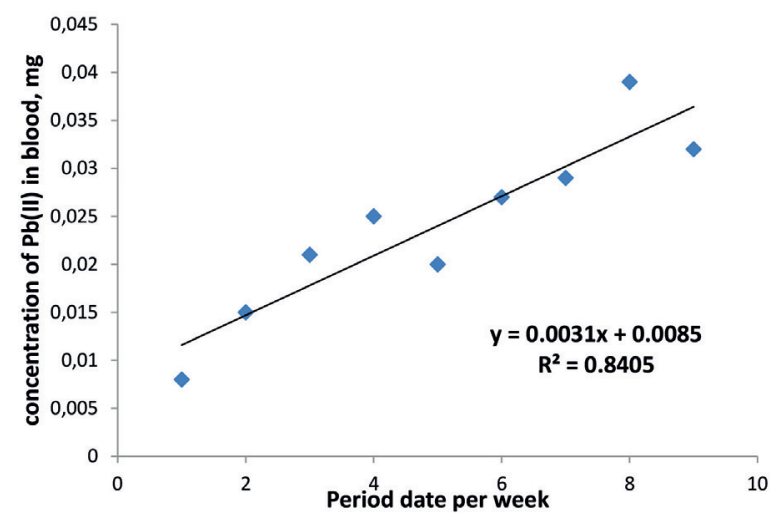

Fig. 3. Lead ( $\mathrm{mg}$ ) in blood of rabbit (injected lead) against time (weeks)

3. ábra Ólom (mg) nyúl vérben (injekciózott ólom) az idő függvényében

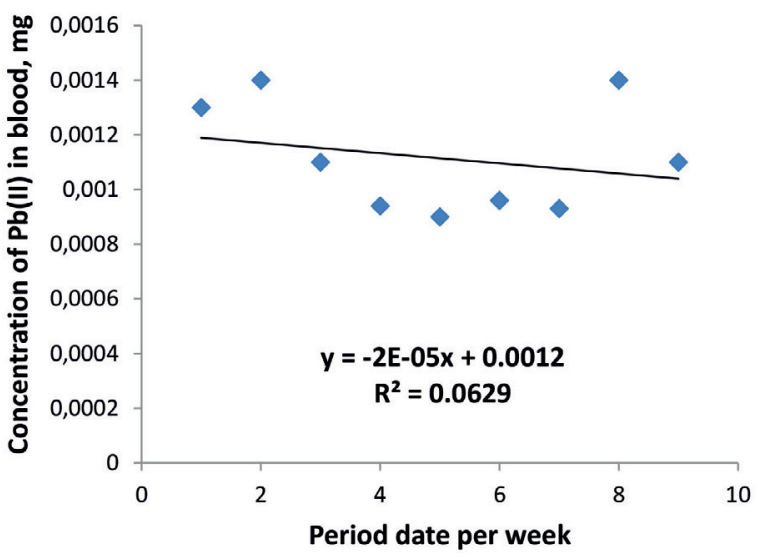

Fig. 4. Lead ( $m g)$ in blood of rabbits fed propolis against time (weeks) 4. ábra Ólom ( $m g$ ) nyúl vérben (propolisszal etetve) az idő függvényében

\section{Conclusion}

The study was included to find the effect of lead ions on the brain of group of rabbits by electrochemical method, also to prove the effect of propolis on the brain of contaminate rabbit with lead ions, it was found the propolis acts as antioxidative reagent which decrease and inhibited effect of lead on the brain of rabbit, so we can said any contamination with lead ions was treated with propolis to stop the oxidation effect of lead ions in blood medium of rabbits.

It can be getting an important conclusion from this research so as to the importance of the special theme of the new diseases such as autism and Alzheimer. It has been studied the blood samples from rabbits exposure to contamination to the lead ions using electrochemical analysis by cyclic voltammetric method, the results show high anodic current peak at $400 \mathrm{mV}$ for the $\mathrm{Pb}(\mathrm{II})$ in the blood samples and this peak was increased against to increasing the dose of $\mathrm{Pb}(\mathrm{II})$ through nine weeks. But the surprise in the results of the analysis for blood samples which received from the rabbit injected with $\mathrm{Pb}$ (II) and feeding with propolis that the oxidation current peak of lead ion was reduced from $8.64 \mathrm{uA}$ to $3.8 \mathrm{uA}$, this mean the concentration of lead ions was reduced from $12.138 \mathrm{mg} / \mathrm{L}$ to $0.417 \mathrm{mg} / \mathrm{L}$ in blood samples. Propolis is one of the most antioxidants acts to inhibition the activity of $\mathrm{Pb}$ (II) in blood medium. So, it can be said that some diseases causes by the contamination with lead ions can be treated with propolis.

\section{References}

[1] Mehta, P. (2012): Cyclic Voltammetric Study of Lead (Pb(II)) in Different Potassium Salts as Supporting Electrolytes, International Journal of Pure Applied Chemistry, Vol. 7, No. 2, pp. 14-21.

[2] Radhi, M. M. - Albakry, A. A. A. - Jassim, A. M. - Alassady, S. A. - AlMulla, E. A. J. (2016): Electrochemical Study of Pb(II) in Present of Each Ascorbic Acid, Glucose, Urea and Uric Acid Using Blood Medium as an Electrolyte, Nano Biomedicine and Engineering, Vol. 8, No. 1, pp. 9-15. https://doi.org.10.5101/nbe.v8i1.p9-15

[3] Radhi, M. M. - Abdullah, H. N. - Jabir, M. S. - Al-Mulla, E. A. J. (2017): Electrochemical Effect of Ascorbic Acid on Redox Current Peaks of $\mathrm{CoCl}_{2}$ in Blood Medium, Nano Biomedicine and Engineering, Vol. 9, No. 2, pp. 103-106. https://doi.org.10.5101/nbe.v9i2.p103-106

[4] Radhi, M. M. (2017): Voltammetric Study of the Redox Current Peaks of $\mathrm{Pb}$ (II) Mediated by GCE in Normal Saline, American Journal of Chemical and Biochemical Engineering, Vol. 2, No. 2, pp. 26-34. https://doi.org.10.11648/j.ejb.20170503.11

[5] Radhi, M. M. - Hussein, B. F. - Mohamed, A. A. (2018): Effect of Omega 3 fatty acid on lead ion anodic current peak in blood of rabbits measured by cyclic voltammetry, Online Journal of Veterinary Research, Vol. 22, No. 1, pp. 1-6, 2018.

[6] Scheller, S. - Szaflarski, J. - Tustanowski, J. - Nolewajka, E. - Stojko, A. (1977): Biological properties and clinical application of propolis. I. Some physico-chemical properties of propolis, Arzneimittel-Forschung, Vol. 27, No. 4, pp. 889-890.

[7] Marín, D. - García, P. (2008): New research on antioxidants, Nova Biomedical Books, New York, 2008.

[8] Nassar, S. A. - Mohamed, A. H. - Soufy, H. - Nasr, S. M. (2013): Protective Effect of Egyptian Propolis against Rabbit Pasteurellosis, BioMed Research International, Volume 2013, Article ID 163724, 9 pages https://doi.org/10.1155/2013/163724

[9] El-Masry, T. A. - Emara, A. M. - El-Shitany, N. A. (2011): Possible protective effect of propolis against lead induced neurotoxicity in animal model, Journal of Evolutionary Biology Research, Vol. 3, No. 1, pp. 4-11. 
[10] Mizrahi, A. - Lensky, Y. (1997): Bee Products: Properties, Applications, and Apitherapy, Springer Science, Business Media, LLC, 1997.

[11] Silva-Carvalho, R. - Baltazar, F. - Almeida-Aguiar, C. (2015): Propolis: A Complex Natural Product with a Plethora of Biological Activities That Can Be Explored for Drug Development, Evidence Based Complementary Alternative Medicine. 2015: 206439 https://doi.org/10.1155/2015/206439

[12] Kilmartin, P. A. - Zou, H. - Waterhouse, A. L. (2001): A cyclic voltammetry method suitable for characterizing antioxidant properties of wine and wine phenolics. Journal of agricultural and food chemistry, Vol. 49, No. 4, pp. 1957-1965. https://doi.org/10.1021/jf001044u

[13] Abdel-Moneim, A. E. - Dkhil, M. A. - Al-Quraishy, S. (2011): The redox status in rats treated with flaxseed oil and lead-induced hepatotoxicity, Biological Trace Element Research, Vol. 143, No. 1, pp. 457-467. https://doi.org/10.1007/s12011-010-8882-z

[14] Elelaimy, I. A. - Elfiky, S. A. - Hassan, A. M. - Ibrahim, H. M. - Elsayad, R. I. (2012): Genotoxicity of anticancer drug Azathioprine (Imuran): role of omega-3 ( $\omega-3)$ oil as protective agent, Journal of Applied Pharmaceutical Science, Vol. 2, No. 4, pp. 14-23. https://doi.org/10.7324/JAPS.2012.2404

[15] Murphy, M. E. P. - Brayer, G. D. - Fetrow, J. S. - Burton, R. E. (1993): The structure and function of omega loop A replacements in cytochrome c. Chemistry, Physics, Polymers \& Materials Science, Vol. 2, No. 9, pp. 14291440. https://doi.org/10.1002/pro.5560020907

[16] Ashton Acton, Q. (2011): Advances in Biotechnology Research and Application: 2011, Amazon.com., USA.
[17] Crespi, B. - Stead, P. - Elliot, M. (2010): Evolution in health and medicine Sackler colloquium: Comparative genomics of autism and schizophrenia. Proceedings of the National Academy of Sciences of the United States of America. Vol. 107, No. 1, pp. 1736-41.

https://doi.org/10.1073/pnas.0906080106

[18] Szpir, M. (2006): Tracing the origins of autism: a spectrum of new studies. Environmental Health Perspectives. Vol. 114, No. 7, pp. A412-8. https://dx.doi.org/10.1289\%2Fehp.114-a412

[19] Burns, A. - Iliffe, S. (2009): Alzheimer's disease. The BMJ. Vol. 338, b158. https://doi.org/10.1136/bmj.b158

[20] Querfurth, H. W. - LaFerla, F. M. (2010): Alzheimers disease. The New England Journal of Medicine. Vol. 362, No. 4, pp. 329-44. https://doi.org/10.1056/NEJMra0909142

[21] Caronna, E. B. - Milunsky, J. M. - Tager-Flusberg, H. (2008): Autism spectrum disorders: clinical and research frontiers. Arch Dis Child. 2008; Vol. 93, No. 6, pp. 518-23. https://doi.org/10.1136/adc.2006.115337

\section{Ref.:}

Radhi, Muhammed Mizher - Hussein, Bahaa Fakhri - Mohamed, Ahmed Adeeb: Electrochemical study of Propolis as anti-oxidative reagent against to lead ions in rabbit blood samples using cyclic voltammetry

Építőanyag - Journal of Silicate Based and Composite Materials, Vol. 71, No. 1 (2019), 28-31. p. https://doi.org/10.14382/epitoanyag-jsbcm.2019.6

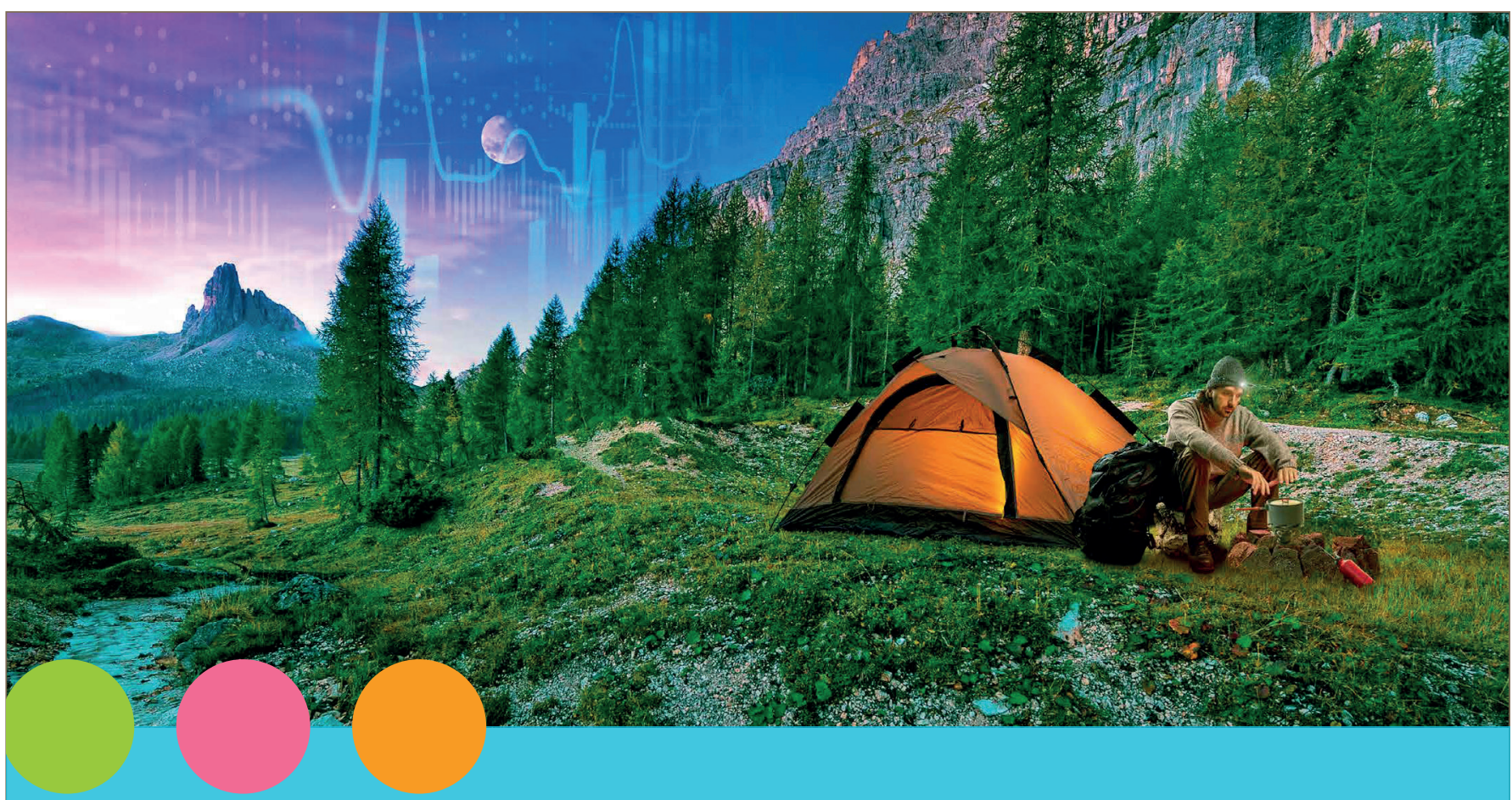

PlasticsEurope is a leading pan-European association and represents plastics manufacturers active in the European plastics industry. The plastics industry in Europe is a vibrant sector that helps improve the quality of life by enabling innovation, facilitating resource efficiency and enhancing climate protection.

In addition to the plastics manufacturers, represented by PlasticsEurope, the plastics industry includes converters, represented by European Plastics Converters (EuPC), recyclers, represented by European Plastics Recyclers (PRE), and machine manufacturers, represented by European Plastics and Rubber Machinery (EUROMAP). 